SONIA WAWRZYNIAK

ORCID 0000-0001-8114-8872

Uniwersytet im. Adama Mickiewicza

$w$ Poznaniu

\title{
TUTORING, MENTORING I COACHING W EDUKACJI OSÓB Z TRUDNOŚCIAMI W UCZENIU SIĘ
}

\begin{abstract}
AвSTRACT. Wawrzyniak Sonia, Tutoring, mentoring $i$ coaching $w$ edukacji osób z trudnościami w uczeniu sie [Tutoring, Mentoring and Coaching in the Education of People with Learning Difficulties]. Studia Edukacyjne nr 56, 2020, Poznań 2020, pp. 221-234. Adam Mickiewicz University Press. ISSN 12336688. DOI: $10.14746 /$ se.2020.56.12
\end{abstract}

The article presents the possibilities it creates using pedagogical innovations such as tutoring, mentoring and coaching supporting the traditional model of education at work with students with school difficulties. Problems withfinding your own path for children and youth, coping skills in a dynamically changing reality, in consumer times with many difficult situations is often undertaken on the basis of school practice and and scientific research.

Young people are expected to have knowledge and skills flexible, mobility in various spheres of life because the change is inscribed in the surrounding reality. Important task of modern school and educational institutions is making young people aware of challenges, that stand before them and prepare them to the right life, educational and professional choices in accordance with their capabilities and requirements of the labor market.

Key words: education, learning difficulties, tutoring, mentoring, coaching, children and youth

Dorośli moga wiele nauczyć się od młodych, którzy pokazują im,

czego nadal maja prawo poszukiwać w swoim życiu. Z kolei sami mogą podzielić się z młodymi ludźmi swoim doświadczeniem, wspierając w ten sposób ich rozwój i dążenie do niezależności.

(D.J. Siegel, 2016, s. 22)

\section{Wstęp}

Młodym ludziom niełatwo w obecnej rzeczywistości ukierunkować jednoznacznie rozwój swojej kariery. Osobom z trudnościami w uczeniu się gorzej niż innym przychodzi zmaganie się wyzwaniami, jakie stawia przed nimi 
codzienna rzeczywistość, gdyż nie zawsze pokrywają się one z ich zasobami i możliwościami. W pracy z uczniami o obniżonych zdolnościach, u których pojawiają się trudności i niepowodzenia wynikające z wielu przyczyn, zwykle główny nacisk zostaje położony na kompensowanie braków, nadrabianie zaległości oraz wyrównywanie wiedzy. O wyborach szkolnych i zawodowych często decydują osoby dorosłe. Zmierza to, niestety, do pogłębienia się niebezpiecznych zjawisk w systemie oświaty zwanych wykluczeniem, izolacją i osamotnieniem. Tymczasem, szkoła powinna być miejscem przyjaznym uczniom o obniżonych zdolnościach i możliwościach, miejscem gwarantującym równe szanse edukacyjne i rzetelne kompetencje zawodowe. Miejscem, w którym uczniom udzielana jest pomoc zgodnie $\mathrm{z}$ ich potrzebami edukacyjnymi oraz miejscem, w którym mają szansę pomimo deficytów rozwijać swoje zdolności. Edukacja to nie tylko nauczanie i wyposażanie w wiedzę, to również troska o całościowe potrzeby danej osoby, a zakres i charakter tych potrzeb w wielu dziedzinach, w tym specjalnych są czynnikami o różnej sile wpływu na poziom efektywności edukacji1 ${ }^{1}$ Wykorzystanie założeń tutoringu, mentoringu i coachingu w warsztacie pracy pedagoga może przełamać wiele dylematów natury edukacyjnej, praktycznej i społecznej, związanych z edukacją uczniów z trudnościami i niepowodzeniami szkolnymi. Szkoła funkcjonuje $\mathrm{w}$ układzie dynamicznym, a dynamizm jest rozumiany jako zdolność do reagowania na wariantowość potrzeb uczniów. Pojawia się więc nowy model szkolnej struktury zwany racjonalno-innowacyjnym² ${ }^{2}$.

Pomimo nieustannych działań na rzecz poprawy edukacji, z roku na rok niepokojąco wzrasta liczba dzieci i młodzieży borykających się z trudnościami w uczeniu się i funkcjonowaniu. Liczba uczniów przerywających naukę przed jej zakończeniem wynosi obecnie, w krajach Europy Zachodniej ponad $20 \%$ populacji. W związku z zaistniałym problemem Rada Europy wydała dokument, dotyczący podjęcia intensywnych działań na rzecz redukcji zjawiska i ograniczenia liczby uczniów przerywających naukę do 10\% w roku 2020 (Concil recommendation on policies to reduce early school leaving, 2011). Problemy te szczególnie dotyczą osób (dzieci i młodzieży) dotkniętych zjawiskiem niepowodzeń szkolnych ze względu między innymi na doświadczany przez nich dysonans poznawczy i emocjonalny. Posiadane, często głęboko zakorzenione deficyty i problemy nie ułatwiają sprostaniu wymaganiom stawianym przez otoczenie społeczne. Tymczasem, podstawowym zadaniem wynikającym ze społecznej roli ucznia jest osiąganie pozytywnych wyników w nauce oraz przygotowanie do pełnienia określonych ról zawodowych i społecznych w życiu dorosłym.

\footnotetext{
${ }^{1}$ J. Jastrząb, Nauczyciel wspótczesnej szkoły jako dydaktyk, wychowawca, diagnosta i terapeuta, Wychowanie na co dzień, 2008, 9(180), s. 2.

${ }^{2}$ M. Budzyński i in. (red.), Tutoring w szkole. Między teoria a praktyka zmiany edukacyjnej, Wrocław 2009.
} 


\section{Trudności w uczeniu się - analiza pojęcia}

Obecnie, w związku ze zmianami warunków i tempa życia oraz wskutek zwiększonych wymagań kształcenia mówi się wręcz o zaburzeniach uczenia się jako o chorobie stulecia ${ }^{3}$. Trudności szkolne mogą dotyczyć każdego dziecka, bez względu na iloraz jego inteligencji i pochodzenie społeczne. Wskaźnikiem trudności w uczeniu się są niepowodzenia szkolne, które

mają swój określony, negatywny wpływ dla układu nerwowego dziecka, jego zdrowia psychicznego, jak i równowagi emocjonalnej. Może to być także przyczyną powstawania wtórnych zaburzeń rozwoju ucznia, rzutujących na jego karierę szkolną ${ }^{4}$.

To grupa deficytów, która dotyczyć może różnych dziedzin wiedzy i umiejętności, powodując trudności z opanowaniem materiału, przystosowaniem się do wymagań szkoły i otoczenia, a także z funkcjonowaniem w grupie rówieśniczej. Samo pojęcie ma interdyscyplinarne znaczenie. Termin trudności w uczeniu się używany jest $\mathrm{w}$ dwóch znaczeniach. W szerokim ujęciu stosowany jest $\mathrm{w}$ odniesieniu do wszelkiego rodzaju trudności w uczeniu się, uwarunkowanych różnymi czynnikami, włącznie z upośledzeniem umysłowym, schorzeniami neurologicznymi, uszkodzeniem mózgu, uszkodzeniem narządów zmysłu i ruchu, a także zaburzeniami emocjonalnymi. W węższym znaczeniu odnosi się do dzieci, które mają trudności w uczeniu się pomimo prawidłowego poziomu inteligencji, dojrzałości w ogólnym rozwoju, przebywania we właściwym środowisku kulturowym i odpowiednich warunków dydaktycznych dla przyswojenia wiedzy i umiejętności szkolnych. Znaczenie to nosi też bardziej adekwatną nazwę - specyficzne trudności w uczeniu się 5 . Według Bogdanowicz termin specyficzne trudności w uczeniu się oznacza zaburzenie jednego lub większej liczby podstawowych procesów psychicznych dotyczących rozumienia mowy ustnej lub pisanej, które mogą mieć związek z zaburzeniami funkcji słuchowych, myślenia, mówienia, czytania, techniki pisania, poprawnej pisowni lub liczenia. Pojęcie to związane jest z zaburzeniami „spostrzegania, uszkodzeniami mózgu, minimalnymi dysfunkcjami mózgu, dysleksją, afazją rozwojową". Termin ten nie obejmuje dzieci, które mają trudności w uczeniu się, będące pierwotnie bezpośrednim rezultatem uszkodzenia wzroku, słuchu lub narządu ruchu; trudności w uczeniu się nie są skutkiem upośledzenia umysłowego lub zaniedbania środowiskowego ${ }^{6}$. Według definicji Stowarzyszenia Dzieci i Dorosłych z Trudnościami w Ucze-

\footnotetext{
${ }^{3}$ L. Wiatrowska, Zróżnicowany obraz dziecka z trudnościami w uczeniu się i rodzicielskiej pomocy, Wychowanie w Rodzinie, 2013, VIII, 2, s. 209.

4 Tamże, s. 211.

${ }^{5}$ M. Bogdanowicz, Specyficzne trudności w czytaniu i pisaniu u dzieci - nowa definicja i miejsce w Klasyfikacjach Międzynarodowych, Psychologia Wychowawcza 1996, 1, s. 13.

${ }^{6}$ Tamże, s. 13-22.
} 
niu się (The Association for Children and Adults with Learning Disabilities - ACLD) specyficzne trudności w uczeniu się

to długotrwały stan, najprawdopodobniej pochodzenia neurologicznego, który w sposób wybiórczy manifestuje się poprzez zakłócenia rozwoju, integracji i realizacji werbalnych oraz niewerbalnych zdolności. Specyficzne trudności w uczeniu się występują jako odmienny rodzaj niepełnosprawności przy zachowaniu przeciętnej lub ponadprzeciętnej inteligencji, prawidłowo funkcjonujących systemów sensorycznych, właściwej sprawności motorycznej i adekwatnych możliwości uczenia się. Trudności te manifestują się w bardzo różny sposób, zarówno jeśli chodzi o ich zakres, jak i stopień nasilenia. W ciągu życia mogą one wpływać na poczucie własnej wartości i samoocenę, edukację, aktywność zawodową, społeczną oraz czynności dnia codziennego ${ }^{7}$.

W tym znaczeniu trudności usytuowane są w kontekście zakresowym pedagogiki specjalnej i przyjmują specyficzny charakter. Natomiast, w ujęciu Zjednoczonego Komitetu do Spraw Trudności w Uczeniu się (National Joint Committee for Learning Disabilities - NJCLD)

to bardzo szeroki termin odnoszący się do bardzo zróżnicowanej grupy zaburzeń, manifestujących się poprzez znaczące trudności w opanowaniu i stosowaniu umiejętności słuchowych, mówienia, czytania, pisania, rozumienia oraz umiejętności matematycznych. Zaburzenia te są pochodzenia wewnętrznego i wydają się być uwarunkowane dysfunkcjami centralnego systemu nerwowego. $Z$ tego też powodu mogą współwystępować z innymi rodzajami niepełnosprawności (np. defektami sensorycznymi, upośledzeniem umysłowym, zaburzeniami rozwoju emocjonalnego i społecznego), jak również z konsekwencjami wpływów środowiska (np. różnice kulturowe, nieodpowiednie lub niewłaściwe wychowanie, czynniki psychogenne), nie są one jednak bezpośrednim następstwem działania tych warunków i wpływów ${ }^{8}$.

Taka interpretacja pojęcia wskazuje na możliwość współwystępowania z trudnościami w uczeniu się innych problemów i dysfunkcji. Do tej grupy należą również uczniowie z nadpobudliwością psychoruchową, zaburzeniami koncentracji uwagi oraz zaburzeniami zachowania. Do najczęściej wymienianych przyczyn trudności w uczeniu się zaliczamy przyczyny: genetyczne, organiczne i biologiczne oraz społeczne. Biorąc pod uwagę problematykę niniejszego artykułu, należy podkreślić znaczenie uwarunkowań społecznych. W tym kontekście „trudności w uczeniu się nie są wrodzone, lecz wyprodukowane. Są symptomem problemów szkoły, a nie ucznia" ${ }^{\prime \prime}$. Uczniowie z niespecyficznymi i specyficznymi trudnościami w uczeniu się należą do grupy dzieci i młodzieży ze specjalnymi potrzebami edukacyjnymi. Jeśli występują

${ }^{7}$ W. Pilecka, Pedagogika osób z trudnościami w uczeniu się, [w:] Pedagogika specjalna, red. W. Dykcik, Poznań 2001, s. 244.

8 Tamże, s. 242.

${ }_{9}$ Tamże, s. 226. 
one długoterminowo i nie zostaną w odpowiednim czasie zdiagnozowane oraz poddane odpowiednim oddziaływaniom, przyniosą negatywne, długofalowe skutki w postaci trudności z budowaniem własnej tożsamości, osiąganiem odpowiednich sprawności społecznych, z samorealizacją i adoptowaniem się do zmian.

Co w kontekście powyższych dylematów może zrobić współczesny pedagog i współczesna szkoła? Zgodnie z zapisem w Ustawie o systemie oświaty, współczesna szkoła ma zapewnić „(...) dostosowanie treści, metod i organizacji nauczania do możliwości psychofizycznych uczniów"10. Proces kształcenia wymaga zatem modernizacji, aktualizacji i innowacji w zakresie działalności dydaktyczno-wychowawczej. Uwydatnia się w tym aspekcie ogromna rola szkoły jako współczesnej organizacji, która powinna brać pod uwagę świadomość potrzeb jednostek, środowiska społecznego i oddziaływania na rzeczywistość, kształtowanie postaw otwartości i szacunku dla innych, przy jednoczesnym budowaniu poczucia współodpowiedzialności oraz dbanie o rozwój i możliwości doskonalenia każdej jednostki ${ }^{11}$. A zatem,

zmiany, do jakich dążyć powinna szkoła, będące jednocześnie nośniami postępu, to świadomie zaplanowane wprowadzenie do systemu szkolnego takich działań, które zawierają w sobie elementy nowości w celu udoskonalania procesu edukacyjnego zgodnie $\mathrm{z}$ wymogami i potrzebami pedagogicznymi ${ }^{12}$

oraz społecznymi i zawodowymi.

Kluczowe dla omówienia tematu wydaje się określenie roli i kompetencji współczesnego nauczyciela, który w myśl opisywanej problematyki powinien stać się mistrzem, przewodnikiem i opiekunem swoich uczniów. Stanisław Dylak wymienia: - kompetencje bazowe związane z osobistymi cechami i umiejętnościami nauczyciela; są to sprawności intelektualne, społeczne, moralne; - kompetencje konieczne umożliwiające wypełnianie zadań edukacyjnych szkoły; zalicza się do nich umiejętności interpretacyjne, autokreacyjne, realizacyjne; - kompetencje pożądane, czyli takie, które budują na mocnych stronach osobowości podmiotów edukacji13. Pojawia się zatem sylwetka współczesnego nauczyciela, która łączy role dydaktyka, wychowawcy, doradcy i terapeuty ${ }^{14}$. Jako podmiot działania doradczego służy radą, wskazuje drogę, lecz nie wyręcza w rozwiązywaniu problemów. Jako terapeuta otacza

${ }^{10}$ Ustawa z 7 września 1991 r. o systemie oświaty (DzU 1991, nr 95, poz. 425), art. 1, p. 4.

${ }^{11}$ M. Christoph, S. Wawrzyniak, Szkoła jako wspótczesna organizacja, [w:] Edukacja jutra. Formy wzbogacania wychowania i zmniejszania zagrożeń społecznych, red. A. Kamińska, P. Oleśkiewicz, Warszawa 2019, s. 89-90.

12 B. Urbanek, Nauczyciel liderem zmiany w edukacji, Nowa Szkoła, 2015, 9, s. 14.

${ }^{13}$ S. Dylak, Wizualizacja w ksztatceniu nauczycieli, Poznań 1995, s. 37.

${ }^{14}$ J. Jastrząb, Nauczyciel wspótczesnej szkoły, s. 3. 
ucznia troską, udziela pomocy, wspiera w samodzielnym działaniu. Stwarza sytuację, inspiruje twórcze poszukiwania, a uczeń podejmuje działania mogąc zawsze liczyć na profesjonalną pomoc.

Tutoring, mentoring i coaching nie stanowią novum w edukacji. W kontekście wspierania procesu edukacji osób z trudnościami w uczeniu się stają się pomysłami na realizację zapisu w ustawie i jednocześnie alternatywnymi sposobami pracy na miarę możliwości i ograniczeń uczniów. Sprzyjają zindywidualizowanemu podejściu w procesie kształcenia.

\section{Mentoring, coaching i tutoring - jako innowacyjne strategie $w$ pracy z osobami z trudnościami w uczeniu się}

Mentoring, coaching i tutoring mają charakter relacji wspierających i budujących pozytywny obraz samego siebie. Różnią się jednak pod niektórymi względami. Mianowicie,

$\mathrm{w}$ procesach coachingowych podopieczny sam definiując swoje cele, wprowadza zmiany w swoim życiu, wykorzystując posiadane przez siebie zasoby, rolą coacha reasumując: trener (coach) jest tym lepszy im „jest go mniej” w procesie zmiany. W ramach tutoringu zaś tutor pełni w większym stopniu rolę ekspercką względem podopiecznego, który chce posiąść wiedzę, umiejętności, kompetencje, którymi dysponuje tutor, co wcale nie oznacza, że chce on być takim, jak ów tutor. W procesach mentoringu istotne znaczenie ma biografia mentora, jego kompetencje, ale i życiowe doświadczenia prowadzące do sukcesu - w tym wypadku podopieczny chce stać się takim jak mentor. Mentor powinien być człowiekiem sukcesu, osobą spełnioną (inną kwestią jest, jak ów sukces personalnie zdefiniujemy i jakie kryteria „spełnienia" przyjmiemy) ${ }^{15}$.

Mentoring to „proces, który stymuluje i wspiera naukę"16, który

zbliża się do sztuki, niż stanowi ścisłą procedurę (...). U jego podstaw leży przeświadczenie o możliwości oddziaływania na drugiego człowieka w jego strefie najbliższego rozwoju, w oparciu o umiejętności (sztukę) wydobywania mocnych stron podopiecznego w ramach epizodów wspólnego zaangażowania ${ }^{17}$.

\section{Idea mentoringu}

zyskała w naszym kraju popularność w ostatnim okresie przede wszystkim w kontekście idei lifelong learning, teorii i praktyki zarządzania zasobami ludzkimi w orga-

${ }^{15}$ M. Piorunek, By(wa)ć mentorem, czyli o dylematach i pułapkach mentoringu, Studia Edukacyjne, 2016, 41, s. 8-9.

${ }^{16}$ E. Parsloe, M. Wray, Trener i mentor, Kraków 2002, s. 81.

${ }^{17}$ M. Piorunek, By $(w a)$ ć mentorem, s. 9. 
nizacjach uczących się, w rozważaniach na styku ekonomii i humanistyki, przynależnych doradztwu personalnemu ${ }^{18}$.

Istnieją określone założenia realizacji tej idei w praktyce szkolnej. Są to między innymi poczucie bezpieczeństwa, stałe uczenie się $\mathrm{w}$ celu doskonalenia, inspiracja ku wyzwaniom, wzmacnianie potencjału jednostek, równowaga $\mathrm{w}$ komunikacji interpersonalnej pomiędzy procesami słuchania i mówienia, pomaganie i wspieranie podopiecznego w działaniu. Stąd też, w katalogu cech mentora powinny znaleźć się takie umiejętności jak samoświadomość, inteligencja emocjonalna, zdolność do pogłębionej refleksji, umiejętności konceptualizacji oraz predyspozycje do pełnienia roli lidera lub przywódcy w formalnych i nieformalnych grupach ${ }^{19}$. Mentor zdecydowanie nie jest gadułą odpowiedzialną za problemy, podejmującym decyzje specjalistą od wszystkiego i przypisującym sobie prawo do decydowania za innych ${ }^{20}$. Mentor pozostaje $\mathrm{w}$ kontakcie z podopiecznym, jest nie tyle nastawiony na jego poznawanie, odkrywanie mocnych stron bądź talentów, co inspiruje i swoją postawą stymuluje jego rozwój. Wyznacza sobie w pracy etapy i dąży do ich realizacji. Są nimi: 1) potwierdzenie planu rozwoju osobistego - realizowane dzięki stymulacji przez mentora samoświadomości podopiecznego; 2) inspirowanie do samodzielnego kierowania nauką; 3) udzielanie wsparcia $w$ realizacji planu rozwoju osobistego; 4) pomoc $\mathrm{w}$ ocenie wyników ${ }^{21}$. Podstawową funkcją mentora w procesie kształcenia jest dzielenie się wiedzą o funkcjonowaniu procesów poznawczych oraz ich efektywnym wykorzystaniu podczas organizacji własnej nauki. Stąd też istnieją "ścieżki”, które pomagają mu uczyć efektywnej nauki²2. Do zadań tych należą: przekazywanie wiedzy o zasadach uczenia się, warunkach organizacji pracy, procedurach działania oraz o stylach uczenia się; udzielanie uczniom informacji zwrotnych na temat ich indywidualnego stylu ucznia się, o zdolnościach i preferencjach. Ponadto, istotnym zadaniem mentora jest nauczanie metod uczenia się poprzez przykład własny, co w efekcie doprowadzi do sytuacji, w której uczące się osoby będą świadome własnych preferencji i posiądą zdolność samodzielnego organizowania sobie nauki i pracy ${ }^{23}$.

Tutoring jest

18 Tamże, s. 8.

19 Tamże, s. 10-13.

20 Tamże, s. 13.

21 A. Sarnat-Ciastko, Tutoring, coaching i mentoring w polskiej szkole? Między chaosem a autentyczną potrzeba. Podstawy Edukacji, 2015, 8, s. 141-147.

22 J. Głębiowska-Szychowska, Ł. Szychowski, Powiem ci, jak się uczyć. Przewodnik dla ambitnych nauczycieli i rodziców, Wydanie I, Gdańsk 2015, s. 27.

23 Tamże, s. 32-34. 
(...) specyficzną metodą oddziaływania pedagogicznego, zakładającą współpracę nauczyciela - tutora z podopiecznym bądź małą grupą podopiecznych, która poprzez działania zaplanowane, formalne, a także nieformalne i spontaniczne prowadzi do rozwoju uczestniczących w niej osób ${ }^{24}$.

W praktyce edukacyjnej wyróżnia się trzy rodzaje tutoringu. Tutoring rozwojowy, którego celem jest wsparcie ucznia w odkrywaniu i rozwijaniu jego talentów oraz wypracowania indywidualnej strategii uczenia się. Naukowy, którego celem jest wspierania rozwoju uczniów, utrwalanie ich wiedzy i umiejętności z określonych dziedzin nauki. Natomiast celem tutoringu artystycznego jest nabycie wiedzy oraz zdolności z różnych dyscyplin sztuki ${ }^{25}$. Tutoring jest procesem składającym się z pięciu wyraźnych etapów: (1) poznania podopiecznego, jego mocnych i słabych stron, budowania z nim dobrej relacji, (2) pomocy w określaniu celów rozwojowych, (3) planowaniu owego rozwoju, (4) realizacji owych planów z uwzględnieniem tutorskiego motywowania i monitorowania, (5) ewaluacji podjętych działann ${ }^{26}$. Realizacja poszczególnych kroków jest możliwa dzięki następującym narzędziom: przejawiania empatii, stawiania pytań otwartych, uważnego słuchania, udzielania informacji zwrotnej oraz koncentrowania się na zasobach ucznia oraz jego przyszłości, a nie deficytach, których źródłem niejednokrotnie była jego przeszłość. Tutor jest nauczycielem wybranym przez ucznia/uczniów, który pracuje z nimi indywidualnie (choć dopuszczalna jest praca z dwoma, trzema podopiecznymi jednocześnie), a optymalna liczba podopiecznych nie powinna być większa niż dziesięć osób. Spotkania odbywają się nie rzadziej niż raz na miesiąc przez 45 minut, zwykle na terenie szkoły ${ }^{27}$. Tutor staje się pewnego rodzaju przewodnikiem, a podopieczny aktywnym uczestnikiem w sytuacji edukacyjnej. Podstawą metody jest partnerska relacja oparta na szacunku, akceptacji i zaangażowaniu. Indywidualne spotkanie dotyczy rozwiązywania problemów, opierając się na mocnych stronach, zasobach ucznia, aby mógł wykorzystać swój potencjał w codziennym działaniu i samorealizacji w równych sferach życia.

Rozwój nowoczesnych technologii i postęp nauki nie pozwala nauczycielowi pozostawać w roli eksperta w określonej dziedzinie wiedzy. Jedynie $30 \%$ informacji i wiedzy o świecie uczniowie zdobywają w szkole, pozostałe 70\% to źródła pozaszkolne. Dlatego coraz ważniejsze stają się kompetencje nauczyciela pełniącego rolę przewodnika,

24 A. Sarnat-Ciastko, Tutoring w polskiej szkole, Warszawa 2015, s. 46.

25 A. Baranowska, Tutoring jako alternatywna metoda pracy z uczniami zdolnymi w szkole, E-mentor, 2014, 5(57), s. 10-19, http:/ / dx.doi.org/10.15219/em57.1136.

26 A. Sarnat-Ciastko, Szkolni tutorzy i rodzice - sprzymierzeńcy czy wrogowie? Prezentacja zastosowania tutoringu jako obszaru do badań nad relacjami szkoła - rodzice, Wychowanie w Rodzinie, 2017, XV, 1, s. 225.

27 Tamże. 
kogoś, kto prowadzi ucznia po jego własnych ścieżkach rozwoju, przestrzega przed niebezpieczeństwami, pomaga w docieraniu do źródeł, pokazuje, jak z tych źródeł czerpać. Taką rolę w stosunku do ucznia pełni tutor - opiekun, wspierający nauczyciel, będący po trochu mistrzem, wychowawcą, doradcą i pedagogiem ${ }^{28}$.

Celem pracy jest rozwój osobowości oraz zainteresowań podopiecznych poprzez wspólne działanie, lecz nie wyręczanie i rozwiązywanie problemów za podopiecznych. W ramach tej strategii pracy mogą być prowadzone tutoriale dla uczniów, w zależności od ich indywidualnych potrzeb (zarówno dla uczniów objętych indywidualnym nauczaniem, ze specjalnymi potrzebami edukacyjnymi, w tym także uczniów zdolnych). Tutor może również spełniać istotną rolę w edukacji domowej, wprowadzając do sytemu kształcenia nową jakość pracy indywidualnej z uczniem. Jego działania mają niejako charakter prewencyjny. Nie tylko działa profilaktycznie w zakresie niepowodzeń szkolnych, lecz także jest innowacyjnym sposobem niwelowania problemów edukacyjnych, ma rozwijać ucznia i motywować go do nauki, dając szansę na sukces i spełnienie każdemu, bez względu na jego potencjał lub ograniczenia. Porozumienie, współpraca, która pojawia się w kontakcie tutora z podopiecznym dalej przyczyni się do poprawy interakcji, budowania pozytywnych relacji z otoczeniem, „dialogowość w interakcjach i rozwijanie możliwości przyjmowania perspektywy innej osoby są podstawą procesu indywidualizacji oraz moralnej i egzystencjalnej autorefleksji” ${ }^{29}$. Zatem, tutoring "stwarza szansę na przekroczenie ram szkoły i tworzenie sieci osób i instytucji współpracujących ze szkołą" ${ }^{30}$.

Tutor to inaczej mentor korzystający z narzędzi coachingu. Teoria coachingu w edukacji związana jest $\mathrm{z}$ potrzebą podnoszenia jakości i efektywności kształcenia, zgodnie z wymaganiami rynku pracy oraz społeczeństwa. W przypadku osób ze spektrum trudności w uczeniu się jest to szczególnie istotne, gdyż uwidaczniają się zaniedbania związane z ich edukacją w tym zakresie. Są często zagubieni, sfrustrowani, osamotnieni i nieświadomi swojego potencjału. Ich wybory edukacyjne oraz zawodowe są często przypadkowe i dokonywane niesamodzielnie. Wykorzystanie coachingu w pracy z uczniami ze SPE opiera się na poszukiwaniu rozwiązań, a nie tylko analizowaniu przyczyn trudności. Wybiega się w ten sposób niejako w przyszłość, budując jej wizję przez pryzmat samosterowalności jednostki i poczucia koherencji.

Coaching jest narzędziem wspomagania rozwojowych zmian, ale to także pewien styl bycia, styl komunikacji (aktywne, sięgające głębi słuchanie, odzwierciedlanie wypo-

${ }^{28}$ M. Budzyński i in. (red.), Tutoring w szkole, s. 11-12.

29 J. Bałachowicz, Tutoring $w$ rozwoju podmiotowym dziecka, [w:] Nowoczesny wychowawca tutor, mentor, coach, red. J. Bałachowicz, A. Rowicka, Warszawa 2013, s. 19.

${ }^{30}$ S. Krzychała, Tutoring wzmacniający nauczycieli jako zespót, [w:] Tutoring w szkole, s. 39-40. 
wiedzi klienta, feedforward, challenging), styl radzenia sobie z sytuacjami problemowymi (wynikający z faktu, iż profesjonalni coachowie przestrzegają zasad kodeksu etycznego coacha, pracują nad samorozwojem, poddają się superwizjom i wreszcie wzmacniają swoje (i klienta) poczucie wewnątrzsterowności ${ }^{31}$.

W coachingu warto podkreślić charakterystyczne elementy przydatne w procesie kształcenia, których brakuje w szkołach. Tak więc: - w coachingu pracę z osobą rozpoczyna się od dokładnego rozeznania wszystkich aspektów jej funkcjonowania; - zakłada się, iż człowiek biorący udział w całym procesie posiada bogate zasoby własne, z których może skorzystać, aby doprowadzić do poprawy własnej sytuacji; - każdy uczestnik jest tak samo odpowiedzialny za własne zaangażowanie w relację związaną z coachingiem; - proces uczenia się jest w coachingu tak samo ważny, jak samo motywowanie do podjęcia działań ${ }^{32}$. Do zaprojektowania lekcji z wykorzystaniem coachingu przydatny jest model GROW - Goal (cel) - jaki jest cel naszego spotkania? Reality (rzeczywistość) - gdzie jesteś teraz? Options (opcje) - co możesz zrobić by osiągnąć cel? Will (wola) - którą z opcji wybierasz dla siebie? ${ }^{33}$ Zajęcia o tym charakterze z pewnością wpływają na rozwój autonomii uczniów, zwiększają samodzielność w poszukiwaniu rozwiązań dla problemów, czyli zdolność dywergencyjnego myślenia. W literaturze wymienia się zasady coachingu mające potwierdzenie w edukacji. Mianowicie, każdy uczestnik procesu kształcenia ma potencjał oraz możliwości i może je uruchomić, jak też wykorzystać do kreowania własnej przyszłości, opierając się na przeszłości i teraźniejszości; to klient/uczeń decyduje o wyborze tematu spotkań z coachem, czego aktualnie potrzebuje; odbywać się one powinny w atmosferze partnerstwa, zaufania, autorefleksji; celem spotkań powinno być dążenie do zmiany poprzez działanie ${ }^{34}$. Istnieje przekonanie, iż „skuteczny coaching będzie miał efekt piorunujący w postaci pozytywnych zmian, które dotyczyć będą nie tylko osoby bezpośrednio poddanej coachingowi, lecz również jej otoczenia" ${ }^{35}$. Choć zasady coachingu są dość trudne do zrealizowania w szkole, to jednak jego elementy można wykorzystać w doradztwie i pracy na różnych poziomach edukacji, jak też z uczniami o zróżnicowanym potencjale rozwojowym. Z początkiem roku szkolnego 2017/2018 weszły w życie przepisy Ustawy z 14 grudnia 2016 roku - Prawo oświatowe (DzU z 2017,

${ }^{31}$ J. Kozielska, Wykorzystanie coachingu w codzienności szkolnej, 2017, https:/ / www.repozytorium.uni.wroc.pl/dlibra/publication/84064/edition/79636?language=pl, s. 193.

${ }^{32}$ J.L. Pękala, Coach, tutor... wychowawca, 2017 https://repozytorium.uni.wroc.pl/dlibra/ publication/94677, s. 181.

${ }_{33}$ J. Kozielska, Wykorzystanie coachingu, s. 194.

${ }^{34}$ J. Kozielska, A. Skowrońska-Pucka, Coaching - czym jest, a czym nie jest? O możliwościach wykorzystania coachingu jako formy niedyrektywnego wspierania w systemie edukacji, [w:] Dymensje poradnictwa i wsparcia społecznego w perspektywie interdyscyplinarnej, red. M. Piorunek, Poznań 2015, s. 41-42.

${ }^{35}$ D. Clutterbuck, Coaching zespołowy, Poznań 2009, s. 15. 
poz. 59) oraz nowe rozporządzenia - w tym Rozporządzenie Ministra Edukacji Narodowej z 17 marca 2017 roku w sprawie szczegółowej organizacji publicznych szkół i publicznych przedszkoli, które określa procedurę i terminy opracowywania, uzgadniania i zatwierdzania arkusza organizacji pracy w danej placówce. Zgodnie z art. 109 ust. 1 pkt 7 Ustawy - Prawo oświatowe, od 1 września 2017 roku zajęcia z zakresu doradztwa zawodowego stanowią jedną z form działalności dydaktyczno-wychowawczej szkoły ${ }^{36}$. Ponadto,

\begin{abstract}
Rozporządzenie Ministra Edukacji Narodowej z 9 sierpnia 2017 r. w sprawie zasad organizacji i udzielania pomocy psychologiczno-pedagogicznej w publicznych przedszkolach, szkołach i placówkach określa, na czym polega pomoc psychologiczno-pedagogiczna, komu jest udzielana, kto jej udziela w szkołach i placówkach, i w jaki sposób. Doradztwo zawodowe jest realizowane w ramach udzielania pomocy psychologiczno-pedagogicznej organizowanej przez dyrektora szkoły lub placówki we współpracy m.in. z poradniami psychologiczno-pedagogicznymi. Doradca zawodowy definiuje zapotrzebowanie uczniów danej szkoły na informacje dotyczące możliwości dalszego kształcenia, rynku pracy, pomaga uczniom planować dalszą edukację i wyznaczać cele zawodowe, a w efekcie wybrać kierunek kształcenia i zawód - w zgodzie z ich potencjałem, mocnymi stronami, predyspozycjami, zainteresowaniami i uzdolnieniami ${ }^{37}$.
\end{abstract}

Zatem, szkoły oraz poradnie psychologiczno-pedagogiczne mają obowiązek zapewnienia uczniom zajęć z zakresu doradztwa zawodowego oraz planowania kariery, prowadzonych przez wykwalifikowanych doradców lub nauczycieli z odpowiednim przygotowaniem.

Wybór ścieżki edukacyjnej i kariery zawodowej to ważny moment w życiu każdego młodego człowieka, lecz kiedy pojawiają się dodatkowe bariery i niepowodzenia jeszcze trudniej ukierunkować swoje działania na tym polu i odnaleźć się w bogactwie ofert w zakresie kształcenia oraz dynamicznych zmian na rynku pracy. Aby lepiej przygotować uczniów do dalszej edukacji i życia w rzeczywistości zawodowej, trzeba zachęcać ich do współpracy z innymi, pracy nad sobą samym oraz wyposażyć w zdolności do radzenia sobie z trudnościami życiowymi, edukacyjnymi oraz zawodowymi. Dlatego, niezmiernie istotne jest $\mathrm{w}$ tym zakresie zaplecze metodyczne i diagnostyczne oraz ogromna rola doradców, pedagogów, psychologów i innych specjalistów. Do istotnych zadań, jakie powinni oni realizować, zalicza się między innymi prowadzenie konsultacji indywidualnych i zbiorowych, rozpoznawanie ograniczeń i trudności uczniów oraz odkrywanie ich zasobów i potrzeb. Z pewnością wykorzystanie założeń tutoringu, mentoringu i coachingu w działaniach dydaktycznych oraz wychowawczych stanie się pomocne w realizacji wyznaczonych celów.

${ }^{36}$ A. Tyniec, Kariera szkolna i zawodowa uczniów ze specjalnymi potrzebami edukacyjnymi, Warszawa 2018, s. 8.

37 Tamże, s. 9. 


\section{Zakończenie}

W kontekście pracy z osobami z trudnościami w uczeniu się edukacja, w swym wielokierunkowym wymiarze, ma do odegrania zasadniczą rolę, polegającą na zapewnieniu uczniom możliwości i warunków do wielostronnego rozwoju ich osobowości. Warto wymienić szereg zmian oraz korzyści dla uczniów z trudnościami i niepowodzeniami szkolnymi, jakie mogą dokonać się dzięki wprowadzeniu do warsztatu pracy pedagoga założeń tutoringu, mentoringu i coachingu. Opisywane powyżej strategie mogą przynieść pozytywne rezultaty również w postaci budowania pozytywnych relacji i współpracy rodziców, nauczycieli i uczniów oraz wniesienia powiewu świeżości do procesu kształcenia. Uczniowie doświadczający trudności i niepowodzeń szkolnych w codziennej rzeczywistości, doświadczają częściej porażek niż sukcesów. Do oddziaływań o charakterze kompensacyjnym, korygującym i usprawniającym zaburzone funkcje warto włączyć działania wyzwalające potencjał, motywujące oraz przygotowujące jednostki do pełnienia ról społecznych i zawodowych. $Z$ pewnością są to postulaty trudne do realizacji w warunkach współczesnej szkoły. Warto jednak pamiętać i próbować, gdyż zapewnienie poczucia bezpieczeństwa sprzyja mobilizacji do podjęcia wysiłku, wyzwala się aktywność osób współdziałających ze sobą. Bazowanie na mocnych stronach, a nie tylko korygowanie braków i niedoskonałości stymuluje do podnoszenia kompetencji zarówno osób uczących się, jak i nauczających. Stwarza to szansę przekonania, że ma się wpływ na swoje życie i podejmowane decyzje. Uruchomienie potencjału wiedzy i kompetencji poprzez stawianie inspirujących pytań, dzielenie się własnymi doświadczeniami pozwala na czynny udział w wyznaczaniu i doskonaleniu swojej ścieżki rozwoju edukacyjnego i zawodowego. Dostosowanie spotkań do indywidualnych potrzeb i predyspozycji podopiecznych powoduje wzrost wewnętrznej motywacji, inspirację, rozbudza pasję i entuzjazm oraz sprzyja kształtowaniu inteligencji emocjonalnej. Wszystko to pomaga ukształtować umiejętności ważne i potrzebne $\mathrm{w}$ różnych sferach życia jednostki, takie jak: przygotowanie do samokształcenia, poszukiwanie i definiowanie celów, planowanie działań, odpowiednie zarządzanie czasem i pracą, wytrwałość w pracy zawodowej oraz, i przede wszystkim, przełamywanie własnych słabości i ograniczeń. Z pewnością sprzyjają zindywidualizowanemu, wielostronnemu rozwojowi człowieka na różnych szczeblach szkolnictwa, a także w działalności pozaszkolnej oraz budowaniu zdrowej samooceny i autonomii. Ponadto, innowacje pedagogiczne $\mathrm{w}$ postaci tutoringu, mentoringu i coachingu $\mathrm{w}$ pracy z uczniami mogą stać się doskonałym sposobem działań w zakresie profilaktyki trudności w uczeniu się i niepowodzeń szkolnych na różnych jej poziomach. 


\section{Anegdota}

Uczeń poprosił mistrza:

- Jesteś taki mądry. Zawsze masz dobre samopoczucie, nigdy się nie złościsz. Pomóż mi, abym i ja stał się taki jak ty.

Mistrz zgodził się i poprosił ucznia, by ten przyniósł kartofla i plecak.

- Gdy się na kogoś obrazisz lub rozzłościsz i zachowasz urazę - powiedział mistrz - weź jednego kartofla, napisz na nim imię człowieka, z którym miałeś konflikt i włóż kartofla do plecaka.

- To wszystko? - zapytał zdumiony uczeń.

- Nie - odparł mistrz. - Musisz zawsze nosić ten plecak przy sobie. Za każdym razem, gdy się na kogoś pogniewasz - dorzucaj kolejnego kartofla.

Uczeń pilnie wykonywał polecenia mistrza. Mijał czas, plecak wypełnił się kartoflami i stał się ciężki. Noszenie go wszędzie ze sobą było sporą niewygodą. W dodatku, kartofel, który trafił do plecaka jako pierwszy zaczął gnić, pokrył się lepkim śmierdzącym szlamem. Inne kartofle puszczały pędy, psuły się, wydzielały ostry, nieprzyjemny zapach.

Uczeń przyszedł do mistrza i zaczął się skarżyć:

- Nie mogę tego świństwa wszędzie ze sobą nosić. Po pierwsze, plecak jest za ciężki, a po drugie - kartofle się psują. Zaproponuj inne rozwiązanie.

Mistrz odpowiedział:

- To samo dzieje się w twojej duszy. Po prostu nie zauważasz tego od razu. Działania zmieniają się w nawyki. Nawyki stają się charakterem, który produkuje złowonne cechy. Dałem ci możliwość obserwacji tego procesu. Za każdym razem, gdy postanowisz się obrazić lub odwrotnie - obrazić kogoś zastanów się, czy jest ci potrzebny dodatkowy kartofel ${ }^{38}$.

\section{BIBLIOGRAFIA}

Bałachowicz J., Tutoring w rozwoju podmiotowym dziecka, [w:] Nowoczesny wychowawca - tutor, mentor, coach, red. J. Bałachowicz, A. Rowicka, Warszawa 2013.

Baranowska A., Tutoring jako alternatywna metoda pracy z uczniami zdolnymi w szkole, E-mentor, 2014, 5(57), s. 10-19, http:/ / dx.doi.org/10.15219/em57.1136

Bogdanowicz M., Specyficzne trudności w czytaniu i pisaniu u dzieci - nowa definicja i miejsce w Klasyfikacjach Międzynarodowych, Psychologia Wychowawcza 1996, 1.

Budzyński M., Czekierda P., Traczyński J., Zalewski Z., Zembrzuska A. (red.), Tutoring w szkole. Między teoria a praktyka zmiany edukacyjnej, Wrocław 2009.

Christoph M., Wawrzyniak S., Szkoła jako wspótczesna organizacja, [w:] Edukacja jutra. Formy wzbogacania wychowania i zmniejszania zagrożeń społecznych, red. A. Kamińska, P. Oleśkiewicz, Warszawa 2019.

${ }^{38}$ http://czasprzebudzenia.blogspot.com/2013/04/przypowiesc-o-plecaku-i-kartoflach. html, [pobrano z lokalizacji: 25.01.2020]. 
Clutterbuck D., Coaching zespołowy, Poznań 2009.

Dylak S., Wizualizacja w ksztatceniu nauczycieli, Poznań 1995.

Głębiowska-Szychowska J., Szychowski Ł., Powiem ci, jak się uczyć. Przewodnik dla ambitnych nauczycieli i rodziców, Wydanie I, Gdańsk 2015.

http:/ / czasprzebudzenia.blogspot.com/2013/04/przypowiesc-o-plecaku-i-kartoflach. html, [pobrano z lokalizacji: 25.01.2020].

Jastrząb J., Nauczyciel wspótczesnej szkoły jako dydaktyk, wychowawca, diagnosta i terapeuta, Wychowanie na co dzień, 2008, 9(180).

Kozielska J., Wykorzystanie coachingu w codzienności szkolnej, 2017, https:/ / www.repozytorium.uni.wroc.pl/dlibra/publication/84064/edition/79636?language $=$ pl

Kozielska J., Skowrońska-Pucka A., Coaching - czym jest, a czym nie jest? O możliwościach wykorzystania coachingu jako formy niedyrektywnego wspierania w systemie edukacji, [w:] Dymensje poradnictwa $i$ wsparcia społecznego w perspektywie interdyscyplinarnej, red. M. Piorunek, Poznań 2015.

Krzychała S., Tutoring wzmacniający nauczycieli jako zespót, [w:] Tutoring w szkole - między teoria a praktyka zmiany edukacyjnej, red. P. Czekierda, M. Budzyński, J. Traczyński, Z. Zalewski, A. Zembrzuska, Wrocław 2009.

Nawrot D., Eduakcja i szkoła w ksztattowaniu kompetencji uczniów do rynku pracy - między teoria a praktyka, Problemy Profesjologii, 2017, 1.

Parsloe E., Wray M., Trener i mentor, Kraków 2002.

Pękala J.L., Coach, tutor... wychowawca, 2017 https:/ / repozytorium.uni.wroc.pl/dlibra/publication/94677

Pilecka W., Pedagogika osób z trudnościami w uczeniu się, [w:] Pedagogika specjalna, red. W. Dykcik, Poznań 2001.

Piorunek M., By(wa)ć mentorem czyli o dylematach i putapkach mentoringu, Studia Edukacyjne, 2016, 41.

Rozporządzenie Ministra Edukacji Narodowej z 17 marca 2017 r. w sprawie szczegółowej organizacji publicznych szkół i publicznych przedszkoli (DzU z 2017 r., poz. 649).

Sarnat-Ciastko A., Tutoring, coaching i mentoring w polskiej szkole? Między chaosem a autentyczna potrzeba, Podstawy Edukacji, 2015, 8.

Sarnat-Ciastko A., Tutoring w polskiej szkole, Warszawa 2015.

Sarnat-Ciastko A., Szkolni tutorzy i rodzice - sprzymierzeńcy czy wrogowie? Prezentacja zastosowania tutoringu jako obszaru do badań nad relacjami szkoła - rodzice, Wychowanie w Rodzinie, 2017, XV, 1.

Siegel D.J., Burza w mózgu nastolatka. Potencjat okresu dorastania, Podkowa Leśna 2016.

Urbanek B., Nauczyciel liderem zmiany w edukacji, Nowa Szkoła, 2015, 9.

Ustawa z 7 września 1991 r. o systemie oświaty (DzU 1991, nr 95, poz. 425), art. 1, p. 4.

Wiatrowska L., Zróżnicowany obraz dziecka z trudnościami w uczeniu się i rodzicielskiej pomocy, Wychowanie w Rodzinie, 2013, VIII, 2.

Tyniec A., Kariera szkolna i zawodowa uczniów ze specjalnymi potrzebami edukacyjnymi, Warszawa 2018. 